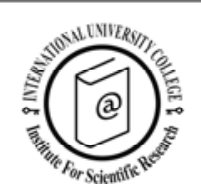

\title{
Film-Induced Tourism: Benefits and Challenges for Destination Marketing
}

\author{
Isil Arikan Saltik ${ }^{1}$, Yesim Cosar ${ }^{1}$ and Metin Kozak ${ }^{1 *}$
}

Received: 18/06/2010 Accepted: 30/11/2010

\footnotetext{
${ }^{1}$ School of Tourism and Hospitality Management, Mugla University, 48170 Mugla, Turkey.

*Corresponding author, e-mail: M.Kozak@superonline.com
}

\begin{abstract}
This paper aims at a qualitative-based empirical investigation of how TV series influences the economic structure and stimulate the publicity of places where it was filmed and which are about to be considered as a visitor attraction in domestic tourism. In order to reach this objective, we have chosen Bozuyuk, a small town of Mugla and located in the south-west part of Turkey. Within the scope of the field study, three excursions were arranged to the town of Bozuyuk where the series was shot, and an on-site observation was made by witnessing both interviews and shooting of the series. Despite the fact that the importance of shooting a series in the region was not understood by the local people in the beginning, all the participants, whom we made interviews with, empasized the contribution of the series in terms of the local economy and publicity. There are some tradesmen approaching the issue particularly in terms of cost-benefit analysis in the light of environment and sustainability. As in Bozuyuk, TV series and movies could aid to counterbalance the lack of causal advertisements for the promotion of places and become a centre of attraction, as a single product itself or as an integrated multiple product, catering for people who like to take short visits. Choosing such a method has an equal impact of spending million dollars for publicity. A further consequence of this study is that gaining a widespread coverage in domestic media and tourism depends on the power of film producers or directors.
\end{abstract}

(C) 2011 International University College. All rights reserved

Keywords: Film-induced tourism, destination marketing, domestic tourism, culture tourism.

Citation: Saltik, I. A., Y. Cosar, M. Kozak (2011) Film-Induced Tourism: Benefits and Challanges for Destination Marketing. European Journal of Tourism Research 4(1), pp. 44-54

\section{Introduction}

Movies are one of the most important factors of popular cultures and have an important influence on the members of a society. Therefore, movies become an important communication tool via product placement. Placing destinations as a product into the movies helps destinations to create a positive image, to be placed as differentiated through the competitors and create an interest for a long-running time. The idea is that, through making the audience become familiar with the destination as a product, movies induce the potential market to visit those destinations 
which are screened or pronounced in movies. Such an effort may, then, help creating a destination brand. Films and TV programs have an impact on consumers while perceiving destinations. Contrarily to the traditional way of advertisement, being shown on the screen as a destination allows destinations to attract more visitors who have an enhanced destination image in their mind by the aid of indirect marketing. For instance, Pratt (2009) claims that serving a movie map in a screened destination leads to an increase in the number of visitors and their spending patterns.

Film-induced tourism has begun to be pronounced more frequent in the recent years as a result of the increased number of visitors arriving at destinations where films or movies have been shot. There has been much research about the film-induced tourism with regard to how the international movies have affected the flow of tourism demand worldwide. Meanwhile, there has also been some additional research about the influence of TV series in this respect (Beeton, 2005; Connel, 2005; Connel \& Meyer, 2008; Frost, 2006; Hudson \& Ritchie, 2006a; O'Connor, et al. 2008; O'neill, et al. 2005; Pratt, 2009; Riley, et al. 1998). In a similar vein, Beeton (2008) also criticizes that, even though the volume of literature about the film-induced tourism has been in a steady growth, there has been little aiming at a detailed investigation of the emotional tie between the film, tourism and recreation. Frost (2006) focuses on how a historic film (Ned Kelly) leads to building of destination image, authenticity and expansion of heritage tourism. Historical films - induced tourism is differentiated from other types of film-induced tourism in two respects. First, the audience wants to own the values of their history. Next, the audience can be affected by other kinds of sources since the plot is already a well-known story.

This paper aims at a qualitative-based empirical investigation of how TV series makes contribution to change the economic structure and stimulate the publicity of those small places where it is filmed and which are about to be considered as a visitor attraction in domestic tourism. An economic impact may occur either in a positive or negative way. New product development may appear as an opportunity to diversify the local tourism industry on a local or regional basis. This way of publicity may sometimes aid the expansion of a particular region into a richer destination by drawing a larger picture of tourism products from nature to culture etc. In order to reach this objective, we have chosen Bozuyuk, a small town of Mugla which is one of the most significant destinations in Turkey. Bozuyuk is located in the south-west part of Turkey with its approxemetly 1000 residents that lead rural life in general (see maps). Over the past few years, Bozuyuk has become a popular centre of attraction because Babaocaği (The Father Home)

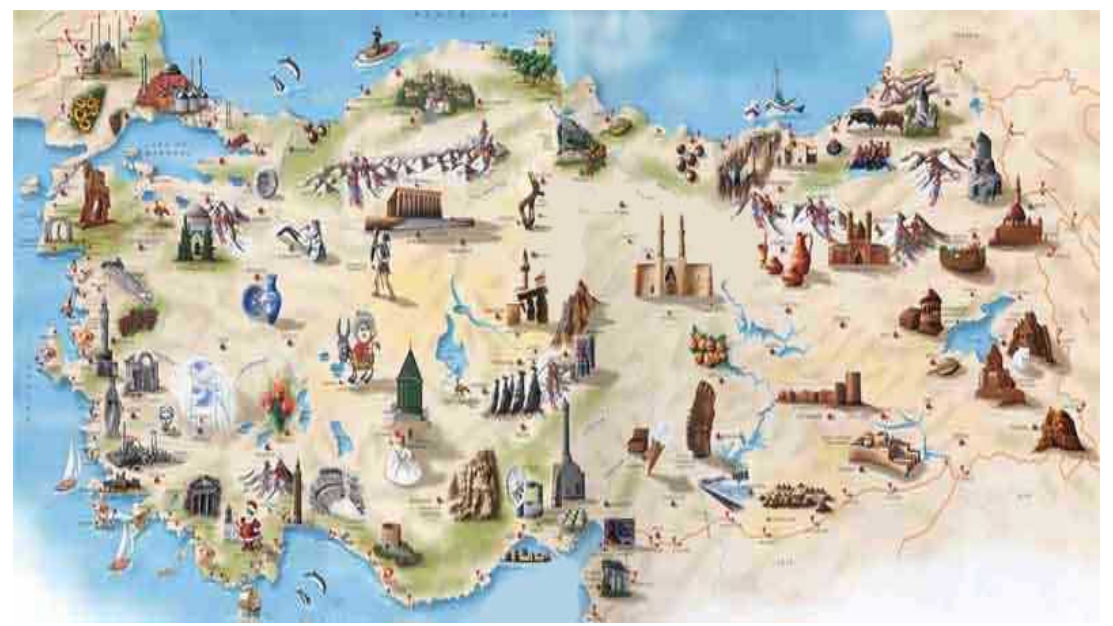

Map 1. An overview of Turkey

Source: Ministry of Culture and Tourism. 


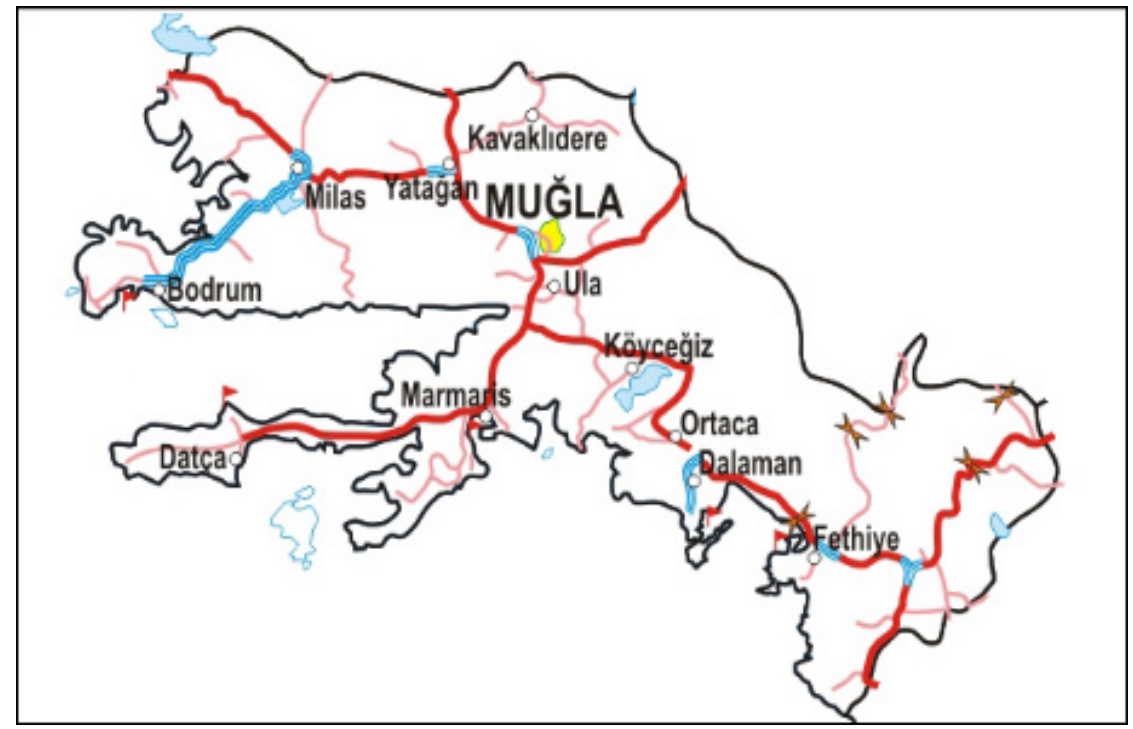

Map 2. The study area

Source: http://www.neredennereye.com/turkiye/mugla/

was shot. This study tries to analyse how Babaocağı has been able to contribute to the publicity of this town in particular, and the region of Mugla in general, during the course of being on the screen as TV series on a national channel.

\section{Literature Review}

Film-induced tourism is defined as a new way to activate or motivate passive visitors after watching any destinations or activities through movies or TV screens (Beeton, 2008). Connel and Meyer (2008) use the term "screen tourism" which contains tourism movements induced by TV programs, videos and movies. Although various researchers tend to call this new type of tourism, like screen tourism (Connell \& Meyer, 2008), movie-induced tourism (Riley et al., 1998) or TV-induced tourism (Connell, 2005a), in this study we prefer the term "film-induced tourism" which consists of movies, TV, on/off-site filming locations (Beeton, 2005). Beeton (2005) also categorizes film-induced tourism into two parts depending upon where the induced tourism activities occur: "on" and "off-film" induced tourism. On-film induced tourism grows up at the destinations where any part of films are shot and shown on the screen, while the latter can be defined as any kinds of events or 46 artificial destinations such as theme parks which are actualized through the involvement in films.

\section{Benefits for Destination Marketing}

Hudson and Ritchie (2006b) assess the profile of previous research carried out on filminduced tourism under four categories: (1) The film impacts over the people's visiting decision, (2) film-induced visitors, (3) the impacts of filminduced tourism over the number of visitors and (4) destination marketing related with filminduced tourism.

First, as for the impacts of films over the decision to visit, in a focus group-based study, Yilmaz and Yolal (2008) conclude that the students are interested in those destinations where a movie is shot, which is mentioned in a movie or even which is pronounced because of another reason in a movie. Destinations promoted through movies might have the possibility for making a sensation in students' minds. While comparing movies and TV series, most students find TV series more interesting and have a long-lasting impact. Macionis (2004) claims that the continuum of filminduced motivation could be used as an important tool while making a travel decision. The most noticeable benefit of encouraging the 
film-induced tourism relates to the promotion of those places where the films are recorded and their consideration as destinations. In the context of being familiar with the influence of visitor behavior over tourism marketing, Kozak (2001) declares that the overall level of satisfaction leads to an increase in the visitors' repeat visit intentions, indicating that experience with a particular destination could stimulate future behavior and repeat visits. As in many other basic marketing books and articles, O'Neill and Busby (2005) also emphasize the importance of "word of mouth recommendation" which is perceived relatively to become cheaper than any other paidadvertisements for destinations. Literaryinduced visitors do not prefer to visit a wellpromoted destination, while the film-induced visitors do. One may also note that there is a two-way interaction between tourism and literary or films. Approximately one-fifth (18\%) of visitors would like to read the book (CCM) and some less would like to watch the film after visiting Cephallonia. This transaction could be called as "an inverse journey from reality to hyper-reality" (O'Neill \& Busby, 2005: 35).

Second, Riley et al. (1998) define the filminduced visitors as people who set out for a destination after watching it on the screen. In other words, the people who are motivated to visit any destination just because of watching it on the screen, as a movie or film, can be called as film-induced visitors.

Finally, the success of the film or literary work leads to an increase in the number of visitors. When the subject is analyzed in terms of tourism marketers, they do not need to care about the authenticity since the achievement of commercial value is more important (Eco, 1987). For example, O'Neill et al.'s (2005) study indicates that the Cephalonian people express a positive opinion that is created by the film of Captain Corelli's Mandolin (CCM). The majority of people think that CCM has positively influenced the image of Cephalonia and, hence, the number of visitors has increased. However, O'Connor et al. (2010a) claim that destination marketers could fail to attract more visitors and income unless they collobrate with film stakeholders although great amount of money is spent by TV companies and thousands of spectators are attracted. Uysal (2009) notes that among the successful utilization of the impact of films on creating consumer demand is achieved by the cigarette industry (Marlboro), textile industry (DenimLevi's), and car industry (Volkswagen BeetleHerbie). Connel (2005b) declares that the impacts of film-induced tourism increased the tourism demand in Balamory. Taking one step ahead, Young and Young (2008) create a model to measure the impacts of film-induced tourism over the number of visitors attracted. They also claim that the effects of film-induced tourism differ among destinations depending on their backgrund.

From the perspective of the association between film-induced tourism and destination marketing, the process of placing destinations into movies offers a great advantage for destinations to promote themselves among the millions of people. This strategy may not be possible by making use of traditional marketing methods. Due to an ever increasing competition and the market becoming crowded gradually, placing destinations in films, TV programs and series is a practice with their lasting impacts which creates the awareness that cannot be reached easily with traditional efforts. Thus, this way of marketing builds a positive image of destinations and ends up with an apparent increase in the number of visitors. As a result, according to Connell and Meyer (2008), the presence of the oriented organizations within the body of national tourism organizations, local authorities and local tourism agencies make the impact of filminduced tourism heavier and the arrangement of visitation to destinations easier and faster. Croy (2010) argues that an image strategy should be created by destination management organisations in order to take the advantage of film-induced tourism as much as possible. In her study, O'Connor (2010) presents an action plan which is called a Film Marketing Action Plan (FMAP) for destination marketers. O'Connor et al. (2010b) suggest that a destination should not be benchmarked with any destination where film-induced tourism has occured while preparing a destination management plan since each destination has its own conditions. It is also noted that there 
are some common basic principles which could be arranged according to various characteristics of destinations.

\section{Challanges for Destination Marketing}

On the other hand, there has been some literature investigating how the influence of filminduced tourism makes the local people or organizations become concerned about its negative side-effects due to a fast-grown popularity or movement (e.g. Connell \& Meyer, 2008; Connell, 2005a). As Mordue (2009) mentions, residents of Goathland where Heartbeat is shot complain about film-induced visitors who interrupt their daily life by coming earlier in the morning, causing traffic jams and overcrowding and leaving back without spending money in the town. Beeton (2008) draws the attention to the question of how difficult to forecast or evaluate the impacts of films on tourism and recreation-oriented locations can be, which, in turn, can be negative or positive. All locations had experienced their own advantages or disadvantages after being promoted as a filminduced destination. Either local authorities or travel agencies organize main activities to promote their new destination by a movie-map or new organized excursions in which visitors can visit the screened locations (Riley et al., 1998). O'Connor and Pratt (2005) support this idea by remarking both number and accomodation duration of visitors and the number of visited places has increased after preparing movie map for 'Pride and Prejudice'. In other words, the movie map plays a significant role while converting potential visitors of destinations into tourism-induced visitors. According to Connell (2005a), many destinations shown on the screen need to deal both with the film-induced visitors and the entrepreneurs who try to convert those cultural or natural sources into cash. As Beeton (2004) also mentions, any difference that occurs between the current image of destinations and the presented image on the screen could negatively influence the direction of destination promotion efforts, particularly on rural tourism.

Even it is hard to ascertain how film-induced tourism movement affected the flow of tourism demand by proper figures or well-documented reports, film-induced tourism has an important role in destination marketing by creating an experience for people even prior to their own experience or presence within the destination (Connell, 2005a). In recent years, marketers have become aware of the magic impact of film-induced tourism in experiential marketing since the traditional way of marketing needs to be diversified. As defined by Pine and Gilmore (1999), experiential marketing focuses on customer experience more than the benefit sought from the product consumption and its three modules such as sensual, emotional and ideational could be achieved easily through the films while marketing destinations. As a result, the destination as a tourism product can be perceived, felt and thought without any personal experience itself (Sheu et al., 2008).

However, looking at the other side of the coin, an uncontrollable increase in tourism demand may disturb not only the local people but also the previous visitor demand due to the deficit of tourism supply at destinations, especially in little towns. As declared by O'Neill et al.'s (2005) study, in constrast with other similar destinations, Cephalonia has missed the opportunities, challenges and benefits of filminduced tourism due to coincidence, dispute, deficiency of entrepreneurs and being unaware of the potential of the film-induced tourism. Kim and Richardson (2003) investigate the influence of a popular motion picture on their empirical study and explain that destination image is clearly affected by films. There should be a destination image management strategy to avoid negative impacts of film-induced tourism since the way of screened position of destinations is not under the control of destination marketers.

\section{Methodology}

Within the scope of the field study, three excursions were arranged to the town of Bozuyuk where the series was shot, and an onsite observation was made by witnessing both interviews and shooting of the series in these days. The interviews were made with the Mayor, the assistant producer, and a restaurant worker, the owner of the coffeehouse forming the brain of the series shooting, two women selling battercake, two workers of Belen 
Coffeehouse and two local people. (09-13-20 February 2009). Each interview lasted for an average of approximately 15-20 minutes. The last interview is the one made with the director lasting for 20 minutes during the camera shooting in the city centre of Mugla (3 March 2009). While one of the researchers was asking questions during the interviews, other two researchers took on the task of taking notes. The notes which were taken during the interviews were typed up by a researcher later on and controlled by other two researchers so as to correct the deficiencies. A document of 15 pages was analyzed, and the following summary information was acquired.

The questions with short contents were asked to the director of the series and the assistant director. In the first part, the subject of the conversation was why the town of Bozuyuk and the name of Family home were chosen, and whether the scenario had been built in advance or it was built according to the development after coming to the town. The second part tried to explain the importance of the series in terms of the introduction of town or the city in general, and whether it was considered that people watching the series would say "Let's see that Bozuyuk". In the last part, the wish of the business enterprises especially those working in the field of tourism for being sponsors and which aspects / districts of Mugla they planned to give prominence were dealt with. In addition, the Mayor and other local people were asked about the perceived potential changes experienced in the town, how they would react to accepting visitors in the future, and whether they thought of making activities with the purpose of tourism. Some conversations were made about their opinions with regard to whether the content (characters) of the series reflected this region, and whether the local people had problems or complaints about the visitors.

\section{Product Development - Publicity}

Although the director of series suggests no particular reason to contribute to the publicity of the town to be recognised as a visitor attraction, our interviewees observe that the audience of the series had become more and more interested in shooting sites after the first parts of the series were broadcasted. When the series was broadcasted for the first time, no one came. Mobility has begun since September 2008. The series set hosted many families with children at weekends and on weekdays particularly in the semester holiday. Previous films such as Bride Ümmü (Ümmü Gelin), Forester (Ormancı), and Ice cream, I Scream (Dondurmam Gaymak) which were shot in this region beforehand did not have any influence on people, and no one came there. The local people think as follows: "People watched the film once; however, the number of people still increases as people watch the series every week." Identically, the director of the series explains his opinions with regards to the relation of tourism - the series - publicity as follows:

My priority was not to introduce Mugla or Bozuyuk, but to enable people to like the series. At the same time, we expected the number of visitors to increase as a result of people liked the series. Visitors especially from adjacent cities started to come following the series. While some people come directly for Bozuyuk, some other people come by saying "Let's see it, and then go" after seeing the signboard... The series will provide Bozuyuk with mobility in domestic tourism at least for one or two years. Mugla is already a well-known place since it has places such as Marmaris, Bodrum, Fethiye, which have very great tourism potentials... A film was shot in Bozuyuk previously; however, it did not have much influence since it did not last for a long time. As for this series, it has been shot for a year constantly and people watch it every week. Therefore, its influence will be more permanent...

The scenario was formed out of the director's own life. As the region began to be recognized by the production team, the scenario included the themes such as Ula Lake, works of olive, camel wrestles and Mugla University. On condition that the main story is maintained, certain orientations are made towards various themes in the parts of the series with the aim of making people laugh and cry. Within this scope, the main purpose is not to promote Mugla as a destination. In fact, the production team does not know Mugla, either. It is not 
considered to make shooting in popular regions such as Bodrum and Marmaris. However, new places are included into the scenario as the production team becomes acquainted with the region, and the way of enriching the story by making shootings in these places is applied. It is explained that making shootings in adjacent places to Bozuyuk does not aim to promote these regions, either. One may argue that giving place to elements such as plateau houses, Mugla architecture, Akyaka, camel wrestles and Turkish bath which reflect the local figures will be beneficial for the regional publicity as well as for the local presentation.

The local people began to appropriate and lean towards the works which were conducted in accordance with the protection of the region's fabric and the certain obstructions (such as that plastic frame is not allowed instead of hardwood). The Mayor says that, with the promotion of TV series, the region was introduced largely to the public and that the number of visitors to Pınarbaşı Restaurant doubled. The expectation is that Cemil Toksöz Mansion whose restoration works are still continued will render service as a boutique hotel consisting of $15-20$ rooms. Hacı Şükrü House, another example of boutique hotel, will be in service soon. The Mayor expresses that Bozuyuk is an urban site area which has conserved its fabric, and therefore it attracts the attention of people. He mentions that certain works are conducted by Mugla Governorship for Bozuyuk to be catered for those people as visitors, which these works have accelerated with the beginning of series' shooting, and that a project under the name of "Street Dressing Project" was drawn by the site committee. This is the hope to solve the bed capacity problem in Bozuyuk, a candidate in culture tourism. The main purpose of governorship's project is to create a culture triangle in the neighbourhood of Yatagan; there will be Belen Coffeehouse at one corner of the triangle, Bozuyuk-Pınarbaşı at the other one and Stratonika at the third corner. In terms of spreading the tourism season all over the year, the Mayor explains this situation as follows:

Bozuyuk has the capacity of being fivetenfold better than Şirince. The fact that it is close to Marmaris, Bodrum and Gökova is a great advantage to develop in culture tourism and to be well known. People would prefer Bozuyuk since it has unspoilt nature, it is an authentic place and it can be reached easily in addition to the reasons that people are bored of the triplet of sea - sand - sun and they cannot find any place to go in the winter months as this triplet is possible only in the summer.

Analysing the subject in terms of regional marketing and regional publicity, it is seen that shootings of the series make a contribution to the other tourism attractions which are close to the town. According to our interview with the keeper of Belen Coffeehouse, where a few parts of the series were shot and which is in the distance of $7 \mathrm{~km}$ to the region of Bozuyuk, those who watch the shootings of the series also tend to visit the Belen Coffeehouse. Approximately 30,000 visitors came to the region in 2008 while there were more customers in the winter compared to the last winter. Through the rule of criss-cross selling, there is a two-directional visitor movement between Bozuyuk and Belen. There were also people coming in summer months but had to return since there was no place to stay overnight. The expectation for the following summer seasons is high. The tumbledown building which is in one step ahead of the coffeehouse is to be restored as a boarding house and restaurant. This region is preferred by people since it has a beautiful landscape and the fact that the region is high and prevents it in the summer months from being very hot. An agency often brings groups from Istanbul in the summer months, and women come as groups from the adjacent cities (especially from Aydın). The Belen Coffeehouse is well-known in Turkey since there is a song written in the name of the Belen Coffeehouse and there is a story being the subject of this song.

As for the future, ambiguity with regard to the question of whether the present success is likely to continue or not still exists. The coffeehouse is presented by hanging photos of shootings on its wall, and in that way the coffeehouse attracts visitors. However, no expectation exists for the coffeehouse to be 
transfered into a museum in the future. The local people are not enterprising, they do not want to give up their habits and change their lifestyles. They do not intend to go beyond of their daily incomes. They would prefer spending what they earn in the summer months in the winter by sitting in the coffeehouse. Thus, they have no idea of making an investment in parallel with the opportunities the series is likely to provide. From this point of view, Mr. Celal thinks that shooting of the series contributes to Bozuyuk community more in terms of culture than economy. He states that the community got used to extraordinary scenes and developed their communication skills. He also mentions the fact that the local people do not have much courage in terms of making something economical by using the influence of the series. He says that the series provided the region with whatever was necessary, and that the rest of the duty is in the responsibility of the local people. Within this scope, the opinions of the owner of the first coffeehouse which was one of the three coffeehouses in the town and which became very famous can be taken into consideration:

I do not think of doing anything since a consistent increase in the number visitors is not present. I hang the photos of the series on the wall, and we move them away while the shooting is made. I even become lazy to hang them again. My friends tell me to change the name of the coffeehouse and to make it "Family Home Coffeehouse", [this name is used now] but I do not want to change it. I do not want its nature to be spoilt ... They tell me to sell the photographs (Family Home Postcards), but then it becomes necessary to deal with it. I do not deal with it since I think that it is not worth doing so. Maybe, it is sold or not. A team of 20-25 people came from Aydın and had breakfast the other day. They said they should arrange a tour, but no one came and asked other than them. It is not clear whether these things will go on in this way. I do not attempt to do anything unless there is constancy...

Some of the village inhabitants are cautious and they state waiting is the appropriate thing to do at the moment. Mr. Cavit (owner of coffeehouse) explains that they think of doing something intended for visitors if they happen to come; however, they want to observe a potential difference at first. If they see that the interest in Bozuyuk is not satisfactory, they do not think of doing anything at all. We learn that photographs related to the shooting of the series can be pressed as postcards, but he is concerned of doing so at the moment. He states that prior to the shooting of the series he used to make 5 litres of buttermilk a day, however now he makes 10 litres and even this amount is not sufficient for some days. Mr. Cavit mentions about organising tours to Bozuyuk at the weekends for groups of 20-25 people from Aydın coming to watch the shooting of the series. As for Mr. Celal, he has plans of presenting regional dishes pertaining to the town (like kidney bean) and special dishes in the boutique hotel, and selling fabrics pertaining to the region and the goods which are hand made by the local people.

\section{Conclusion and Implications}

From the perspective of social transition in a community, as in many other countries, TV series have become a central point of people's interests to compensate their spare time over the recent years. On the other side, from an economic perspective, there has also been a steady growth in the volume of TV series and the amount of money invested in this respect. The academic studies have also gained much attention to discuss the impact of TV series over the places shot in terms of economic, social and environmental consequences. Therefore, this study aims at a qualitativebased empirical investigation of how the TV series may impact upon the economic development of the places and the way of their promotion as a new destination product to be introduced into the line of domestic tourism movements. While the series was still being shot and shown on TV simultaneously, we had the success of obtaining a mixture of detailed and fresh opinions by being able to conduct an interview with various bodies of the village community, e.g. mayor, residents, business owners and film producers.

Despite the fact that the importance of shooting a series in the region was not understood by the local people in the beginning, all the 
participants with whom we made interviews stressed the contribution of the series to the town in terms of economy and publicity. In addition to those coming to watch the shooting of series, there are also people directing their acquaintances for it. These people who come to watch the shooting of the series go to markets, sit in coffeehouses, go to hairdressers, and dine at restaurants. Briefly, visitors spend money. In contradiction to the old customer profile, the people coming from adjacent cities and towns have begun to gain intensity. Although the people come to watch the shooting of the series and browse around, they go to restaurants in their second visits. With regards to the influence of this acceleration on the economic structure of Bozuyuk in the future, the expectation of tradesmen for the following summer seasons is more visitors to come. However, it should be reminded that film-induced tourism occurs incidentally unless the main objective of filming is to achieve film-induced tourism (Beeton, 2004).

We see the fact that films are one of the most important motivators for the local public and private organizations to activate demand for their locations perceived to be a kind of tourism product after being involved in the film industry as a product. As indicated by Yilmaz and Yolal (2008), there is a clear link between filminduced tourism and destination image in the context of marketing for culture tourism. When any part of a film is shot in a specific place, it creates positive impacts over its perceived image among the audience. Since the term "destination image" has a direct influence over human behavior, towns or villages as destinations should be differentiated from their counterparts and promoted to have a different position in order to make a sensation in visitors' minds. This idea makes more sense if one revisits the proposal that one product can be differentiated by the varied experiences (Prentice et al., 1998). This means that just because of watching a place on movies or TV series, or visiting this place in person, may influence people's minds to consider this place a different experience. As such, Bozuyuk has the possibility of becoming a favourable visitor or attraction centre, such as Şirince (Izmir), by restoring the old buildings with an investment of one million dollars. This may aid to expand the tourism season in Mugla into 12 months.

Through the advantage of information technology and mass media (Laing \& Crouch, 2009; Moyle \& Croy, 2009), marketing agencies or people may gain the benefit of developing their places as destinations and promoting them as a new product either in domestic or international tourism market. As in Bozuyuk, TV series and movies might aid to counterbalance the lack of causal advertisements for the promotion of places and to become a centre of attractions, as a single product itself or as an integrated multiple product, catering for people who like to take short visits. Choosing such a method has an equal impact of spending million dollars for publicity. Noting the short-sided influence of previous TV movies or series, a greater emphasize needs to be given to establishing a strong collaboration between public and private bodies to obtain as much benefit as possible for the credit of local people's involvement in such a transformation. A further consequence of this study is that gaining a widespread coverage in domestic media and tourism depends on the power of film producers or directors.

However, as mentioned above, there are several local residents who are not sure about how much this acceleration may continue avoiding giving clear knowledge regarding what is to be accomplished. Such a thought may be arising for various reasons. It is necessary to argue that the local tradesmen are right in thinking of that way considering the current situations of other towns experiencing similar conditions after certain series which were shot in the previous years in other towns of Turkey. There are some tradesmen approaching the issue particularly in terms of cost-benefit analysis in the light of environment and sustainability. On the other hand, it is also possible to gain minimal impacts in terms of multiplier effects for the destination, as after Bollywood productions occur since Babaoacağı is considered as a low-budget TV series (Ward \& O'Regan, 2009). 


\section{Acknowledgements}

An earlier version of this paper was presented at the $3^{\text {rd }}$ Advances in Tourism Marketing Conference, Bournemouth, UK, 10-12 September 2009.

\section{References}

Beeton, S. (2008). From the screen to the field: the influence of film on tourism and recreation. Tourism Recreation Research, 33(1), 39-47.

Beeton, S. (2005). Aspects of Tourism Filminduced Tourism. Channel View Publications.

Beeton, S. (2004). Rural tourism in Australia Has the gaze altered? Tracking rural images through film and tourism promotion. International Journal of Tourism Research, 6(3), 125- 35.

Connell, J. (2005a). Toddlers, tourism and Tobermory: Destination marketing issues and television-induced tourism. Tourism Management, 26(5), 763-776.

Connell, J. (2005b). 'What's the story in Balamory?': The impacts of a children's TV programme on small tourism enterprises on the isle of Mull, Scotland. Journal of Sustainable Tourism, 13(3), 228-255.

Connell, J. \& Meyer, D. (2009) Balomory revisited: An evaluation of the screen tourism destination-tourist nexus. Tourism Management 30(2), 194-207.

Croy, W. G. (2010). Planning for Film Tourism: Active Destination Image Management. Tourism and Hospitality Planning and Development, 7(1), 21-30.

Eco, U. (1987) Travels in Hyper-Reality. London: Pan Books.

Frost, W. (2006) Braveheart-ed Ned Kelly: Historic films, heritage tourism and destination image. Tourism Management, 27(2), 247-254.

Hudson, S. \& Ritchie, J.R. (2006a) Film tourism and destination marketing: The case of Captain Corelli's Mandolin. Journal of Vacation Marketing, 12 (3), 256-268.

Hudson, S. \& Ritchie, J.R. (2006b) Promoting destinations via film tourism: An empirical identification of supporting marketing initiatives. Journal of Travel Research, 44(4), 387-396.
Kim, H. \& Richardson, S. L. (2003). Motion picture impacts on destination images. Annals of Tourism Research, 30(1), $216-237$

Kozak, M. (2001) Repeaters' behavior at two distinct destinations. Annals of Tourism Research, 28 (3), 784-807.

Laing, J.H. \& Crouch, G.I. (2009). Exploring the Role of the media in shaping motivations behind frontier travel experiences. Tourism Analysis, 14(2), 187-198.

Macionis, N. (2004). Understanding the filminduced tourist. In Frost, W., Cory, G., Beeton, S. (ed). (2004) International Tourism and Media Conference Proceedings, $24^{\text {th }}-26^{\text {th }}$ November 2004. Melbourne: Tourism Research Unit, Monash University, 86 - 97.

Mordue, T. (2009). Television, tourism and rural life. Journal of Travel Research, 47(3), 332- 345.

Moyle, B.D. \& Croy, W.G. (2009). Media in the previsit stage of the tourist Experience: Port Campbell National Park. Tourism Analysis, 14(2), 199-208.

O'Connor, N. (2010). A film marketing action plan (FMAP) for film-induced tourism destinations using Yorkshire (UK) as the case study area. Doctoral dissertation summary. European Journal of Tourism Research, 3(1), 1-3.

O'Connor, N. and Pratt, S. (2005). Using movie maps to leverage a tourism destination - Pride and Prejudice. URL: http://lit.academia.edu/NoelleOConnor/ Talks/2428/Using_movie_maps_to_lev erage_a_tourism_destination_Pride_and (Accessed on 01.11.2010).

O'Connor, N., Flanagan, S. \& Gilbert, D. (2008). The integration of film induced tourism and destination branding in Yorkshire, U. K. International Journal of Tourism Research, 10(5), 423 - 437.

O'Connor, N., Flanagan, S. \& Gilbert, D. (2010a). The capitalizing of the filminduced tourism phenomenon through stakeholder collaboration in Yorkshire, UK. e-Review of Tourism Research (eRTR), 8(1), 1-11.

O'Connor, N., Flanagan, S. \& Gilbert, D. (2010b). The use of film in re-imaging a 
tourism destination: a case study of Yorkshire, UK. Journal of Vacation Marketing, 16(1), $61-74$.

O'Neill, K., Butts, S. \& Busby, G. (2005). The Corellification of Cephallonian tourism. Anatolia: An International Journal of Tourism and Hospitality Research, 16(2), 207-226.

O'Neill, K. \& Busby, G. (2005). The influence of Captain Corelli's mandolin on tourism to Cephallonia. Paper presented at International Tourism Conference Perspectives in Tourism Marketing, $20^{\text {th }}-22^{\text {nd }}$ May, Mugla, Turkey.

Pine, J.B. \& Gilmore, J.H. (1999). The Experience Economy: Work is Theatre \& Every Business a Stage. Boston: Harvard Business School Press.

Pratt, S. (2009) A movie map conversation study: A case study of "Pride \& Prejudice", In Kozak, M., Andreu, L., Gnoth, J. (eds.). Advances in Tourism Marketing, Routledge,59-73.

Prentice, R.C., Witt, S.F. \& Hamer, C. (1998). Tourism as experience: The case of heritage parks. Annals of Tourism Research, 25 (1), 1-24.

Riley, R., Baker, D. \& Van Doren, C.S. (1998). Movie-induced tourism. Annals of Tourism Research, 25 (4), 919-935.
Sheu, J-J., Su, Y-H. \& Chu, K-T. (2008) Segmenting online game customersThe perspective of experiential marketing. Expert Systems with Applications, 36 (4), 8487-8495.

Uysal, C. (2009). Where does the Turkish Cinema Lead to the Turkish Tourism, Turizmde Bu Sabah - Online Daily Newspaper 19 January 2009. URL: http://www.turizmdebusabah.com/habe r_detay.asp?haberNo=43810 (Accessed on 21.01.2009).

Ward, S. \& O'regan, T. (2009). The film producer as the long-stay business tourist: Rethinking film and tourism from a Gold Coast perspective. Tourism Geographies, 11(2), 214-232.

Yılmaz, H. \& Yolal, M. (2008) Film tourism: The role of movies in destination marketing. Anadolu University Journal of Social Sciences, 8(1), 175-192.

Young, A. F. \& Young, R. (2008). Measuring the effects of film and television on tourism to screen locations: A theoritical and emprical perspective. Journal of Travel \& Tourism Marketing, 24(2-3), 195-212. 